\title{
EDitorial EDitoriol
}

O volume 29 da Revista Temporalis socializa com o público leitor reflexões críticas relacionadas ao tema do XIV Encontro Nacional de Pesquisadores em Serviço Social (ENPESS): "Lutas sociais e produção de conhecimentos: desafios para o Serviço Social no contexto de crise do capital". Reafirma a direção social assumida hegemonicamente pela categoria profissional dos assistentes sociais desde os anos 1990, ou seja, a crítica ao capital e à sociedade que permite sua produção e reprodução ampliada (o capitalismo), a defesa irrestrita de direitos, ainda que a faça diversa e pluralmente.

Os artigos ora apresentados, 14 no total, estão subdivididos em dois blocos conforme estabelece a Revista: artigos temáticos e artigos de temas livres. Os primeiros cinco textos oferecem reflexões críticas sobre a sociedade do capital, o perfil das políticas em curso, destacando sua objetivação em realidades cujas revoluções burguesas ocorreram pela via colonial e muito tardiamente. Não deixam por isso, ao contrário, de contribuir com o Serviço Social, pois oferecem elementos importantes para decifrar a trama da ordem social hegemônica, sua reprodução no Brasil e na América Latina e suas particularidades no campo das políticas voltadas à gestão do pauperismo. Ainda no mesmo bloco outros quatro artigos tratam, sucessivamente, dos movimentos sociais no Brasil, da crítica à noção de liberdade na sociedade de classes, de alguns traços que subsidiam a crítica ao neoconservadorismo no Serviço Social (pelo viés religioso) e do posicionamento crítico da categoria profissional dos assistentes sociais adensado nas últimas décadas. Os temas livres (cinco no total) particularizam a discussão do bloco anterior tratando de importantes assuntos transversais que destacam temáticas tais como habitação, gênero, violência doméstica e questão racial.

É preciso ressaltar outro aspecto não menos relevante: todos 


\section{tempordlis}

os textos, direta ou indiretamente, sistematizam pesquisas realizadas em diferentes momentos formativos. Revelam, ao mesmo tempo, um ponto de partida essencial para a crítica à ciência abstrata e estranha à "lógica da coisa" (como insistiu Marx e destacou Lukács): a própria realidade, sua dinâmica e assuntos que tratam da vida real de seres reais-concretos. $O$ fazem tendo como referência diversas regiões do Brasil e, certamente, abordagens teóricas não homogêneas comprometidas com certo tipo de crítica.

A atual gestão da Associação Brasileira de Ensino e Pesquisa em Serviço Social (ABEPSS) "Ousadia e Sonho em Tempos de Resistência” (2015/2016) reforça, com isso, os compromissos históricos da categoria profissional dos assistentes sociais, entre eles a defesa do que se convencionou caracterizar coletivamente como "Projeto Ético-Político Profissional”. Reafirma, ainda, o Código de Ética em curso e a defesa irrestrita de uma formação profissional de qualidade, não aligeirada. Ótima leitura crítica a todas (os)!

Raquel Santos Sant'Ana - Presidente Nacional da ABEPSS.

José Fernando Siqueira da Silva - Editor Chefe. 